\title{
Munkovalsaria donacina from grapevines and Desert Ash in Australia
}

\author{
Pitt WM$M^{1}$, Úrbez-Torres $\mathbf{J R}^{2}$ and Trouillas $\mathbf{F P}^{3}$ \\ ${ }^{1}$ Department of Primary Industries, Wagga Wagga Agricultural Institute, Pine Gully Road, Wagga Wagga, New South \\ Wales 2650, Australia. \\ ${ }^{2}$ Agriculture and Agri-Food Canada, Pacific Agri-Food Research Centre, 4200 Highway 97, Box 5000, Summerland, \\ British Columbia VOH1ZO, Canada. \\ ${ }^{3}$ Department of Plant Pathology, University of California, Davis, California 95616, United States of America.
}

Pitt WM, Úrbez-Torres JR, Trouillas FP 2014 - Munkovalsaria donacina from grapevines and Desert Ash in Australia. Mycosphere 5(5), 656-661, Doi 10.5943/mycosphere/5/5/6

\begin{abstract}
A bitunicate ascomycete bearing brown 1-septate ascospores consistent with the botryosphaeriaceous genera Dothiorella and Spencermartinsia was observed on discarded grapevine (Vitis vinifera L.) canes, and in culture was purported to yield a coelomycetous asexual morph in Spencermartinsia. However, morphological studies and amplification and sequencing of the internal transcribed spacer (ITS) region and portions of the small (18S) and large (28S) subunits of the nuclear ribosomal RNA gene identified the ascomycete as Munkovalsaria donacina (Niessl) Aptroot, and revealed that the fungus is neither connected to an asexual morph in Spencermartinsia, nor related to the Botryosphaeriaceae (Botryosphaeriales). Instead, these findings provide the first report of M. donacina from grapevines and Desert Ash (Fraxinus angustifolia subsp. angustifolia Vahl), extending the range of the taxon to 38 species in 24 families.
\end{abstract}

Keywords - Botryosphaeriaceae - Botryosphaeria dieback - grapevine trunk diseases

\section{Introduction}

In November 2009 during an industry survey of vineyards in Western Australia, an unidentified ascomycete bearing bitunicate asci comprising eight brown, thick-walled, 1-septate ascospores, consistent with those of the grapevine (Vitis vinifera L.) trunk disease pathogens Dothiorella and Spencermartinsia, was observed on discarded grapevine canes (Pitt et al. 2013). Following transfer of ascospores to pure culture, a coelomycete with brown, thick-walled, two-celled conidia, pigmented and septate prior to discharge from conidiogenous cells developed in culture. This species was similar to, but distinct from the generic type, Spencermartinsia viticola (A.J.L. Phillips \& J. Luque) A.J.L. Phillips et al., both morphologically and phylogenetically. However, at the time of our original study, we did not introduce a novel combination for this species because supposed ascospores of the fungus lacked the terminal apiculi Phillips et al. (2008) used to typify the genus.

In the interim, three new species have been described in Spencermartinsia from hosts originating from Iran, New Zealand and Spain (Abdollahzadeh et al. 2014), all circumscribed based on phylogeny and morphology of asexual morphs. However, sexual morphs were not observed for any of these species and it remains unclear whether apiculate ascospores are a consistent character of the genus (Phillips et al. 2013). In an attempt to clarify the nature of the association between the 
bitunicate ascomycete and the Spencermartinsia sp. that arose from our original survey, additional field collections were undertaken in September 2013, with the ascomycete collected once again on discarded grapevine canes as well as fallen branches of Desert Ash (Fraxinus angustifolia subsp. angustifolia Vahl), a popular deciduous tree commonly found in gardens and streetscapes. However, in this instance, the transfer of ascospores to culture did not reveal an asexual morph in Spencermartinsia, and instead gave rise to a fungus that was morphologically and phylogenetically unrelated to Botryosphaeriaceae.

The aim of this study was to identify the aforementioned bitunicate ascomycete and resolve the nature of the association between this fungus and the Spencermartinsia sp. that arose from our original collections from diseased grapevines in Western Australia.

\section{Materials and Methods}

\section{Fungal isolates}

Axenic single spore cultures of an ascomycete observed both on discarded grapevine canes and fallen branches of Desert Ash were obtained on 1.5\% water agar (BD Difco technical agar; Benton, Dickinson and Company, North Ryde, Australia) according to Crous (2000). After incubating overnight at $25^{\circ} \mathrm{C}$, single germinating ascospores were then transferred to potato dextrose agar supplemented with $50 \mu \mathrm{g} / \mathrm{mL}$ of streptomycin sulfate (PDA-Strep; Sigma-Aldrich, Castle Hill, Australia).

\section{Morphology and culture characteristics}

Perithecial contents from ascomata were mounted in water, and microscopic examinations thereof conducted with a Zeiss Axiophot compound microscope with DIC optics and captured using a Nikon D700 digital camera. Digital images of fungal strains including the lengths and widths of ascospores were recorded using Image-Pro@ $\odot$ Plus software (v4.5.1.29, Media Cybernetics, Inc.). Mean, standard deviation and 95\% confidence intervals were recorded for at least 50 ascospores per specimen and are given in $\mu \mathrm{m}$, with extremes in brackets. To study colony morphology, cultures were maintained in incubators under controlled conditions of 12/12 hour photoperiod (fluorescent light) at $25^{\circ} \mathrm{C}$ for eight weeks. Colony colour (Rayner 1970) and growth rates (Sánchez et al. 2003) were determined on PDA. Material comprising ascomata and cultures of the fungus were submitted to the Plant Pathology Herbarium (DAR), Orange, Australia (DAR80529, DAR82454, DAR82455).

\section{DNA extraction, PCR amplification and sequencing}

Genomic DNA was extracted from seven day-old pure cultures grown in potato dextrose broth (PDB; Oxoid Ltd., Basingstoke, Hampshire, England) incubated at room temperature as described by Pitt et al. (2013). Amplification and sequencing of the internal transcribed spacer (ITS) region was performed as described by Pitt et al. (2013) using primer pairs ITS1 and ITS4 (White et al. 1990), while portions of the small subunit (18S) nuclear ribosomal RNA gene (SSU) and large subunit (28S) nuclear ribosomal RNA gene (LSU) were amplified and sequenced according to Zhang et al. (2009) using primer pairs, NS1 and NS4 (White et al. 1990) and LR5 and LROR (Vilgalys \& Hester 1990, Rehner \& Samuels 1994), respectively. DNA sequences of the ITS, SSU and LSU regions from isolate DAR82455 were submitted to GenBank (KJ628375, KJ628376, KJ628377).

\section{Results}

Amplification and sequencing of the ITS, SSU and LSU regions from an asexual morph that developed from single ascospores of a bitunicate ascomycete collected from grapevines in Western Australia displayed high similarity to the didymosporous genera Phaeodothis Syd. \& P. Syd. (9599\% homology over the three regions), Montagnula Berl. (88-99\%) and Munkovalsaria Aptroot (8897\%). 
When examined, material collected from discarded grapevine canes and fallen branches of Desert Ash bore immersed, gregarious, clypei encircled ascomata. Asci were clavate, bitunicate with a long pedicel and small ocular chamber and comprised eight, ellipsoid ascospores per ascus, arranged irregularly to biseriately, initially hyaline, thin-walled and unicellular, but becoming brown, thick-walled and unequally 1-septate with age. Ascospores were strongly constricted at the septum with the upper cell wider and pointed and lower cell longer and rounded, and morphologically were conspecific in all respects with those of the generic type, Munkovalsaria donacina (Niessl) Aptroot (Fig.1).
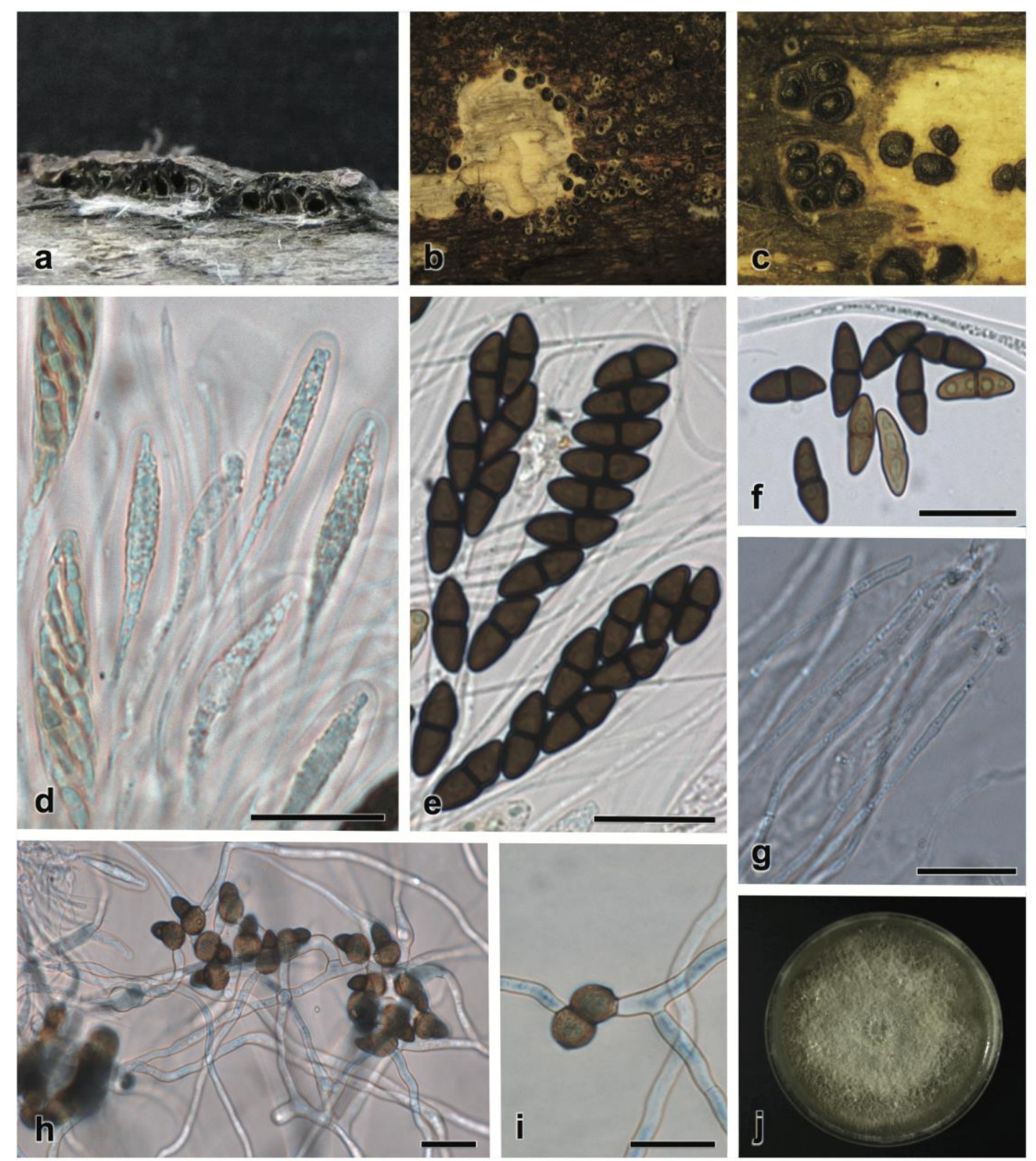

Fig. 1 - Munkovalsaria donacina. a) ascomata erumpent on surface of fallen branches of Desert Ash. b) emerging pseudothecial ostioles surrounded by clypeus on discarded grapevine canes. c) aggregated pseudothecial cavities on discarded grapevine canes. d) immature bitunicate asci with long pedicel and small ocular chamber. e) mature asci bearing eight brown 1-septate ascospores arranged biseriately. f) immature hyaline and mature brown 1-septate ascospores. g) septate pseudoparaphyses. h) tight clusters of eight germinating ascospores originating from single ascus. i) single germinating ascospore. j) 28 day-old colony of $M$. donacina (DAR82455) on PDA. - Scale bars: $\mathrm{d}, \mathrm{e}, \mathrm{h}, \mathrm{i}=50 \mu \mathrm{m} ; \mathrm{f}, \mathrm{g}=20 \mu \mathrm{m}$. 


\section{Taxonomy}

Munkovalsaria donacina (Niessl) Aptroot, Nova Hedwigia 60(3-4): 3461995.

Fig. 1

MycoBank 413489

= Microthelia donacina Niessl in Thümen, Contrib. Flor. Mycol. Lusitan.: no. 5361879.

$\equiv$ Didymosphaeria donacina (Niessl) Sacc., Syll. Fung. 1: 7151882.

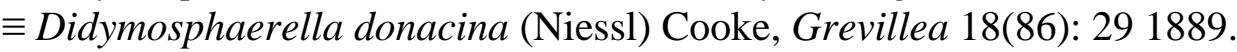

The material is consistent with $M$. donacina, with immersed to erumpent, black, globose to pyriform, pseudothecial ascomata, arising singly or gregarious with clypei surrounding the ostioles. Asci clavate, bitunicate with a long pedicel and small ocular chamber. Ascospores ellipsoid, eight per ascus, arranged irregularly to biseriately, initially hyaline, thin-walled, unicellular, becoming brown, thick-walled, and unequally 1-septate and strongly constricted at the septum, with the upper cell wider and pointed and lower cell longer and rounded, measuring (13.6) 14.8-15.2 (17.3) × (6.6) 7.5-7.7 (8.3) $\mu \mathrm{m}$, with mean length and width of $15 \pm 0.7 \times 7.6 \pm 0.4 \mu \mathrm{m}$, and an average length to width ratio of $2 \pm 0.1(\mathrm{n}=100)$. Pseudoparaphyses trabeculate, septate and ramified, up to $\sim 3 \mu \mathrm{m}$ in width.

Cultural characteristics - On PDA colonies filamentous, creamy white with raised dense cottony mycelium in the centre, becoming light to pale citrate $(21 \mathrm{k})$ at the margin after 28 days under near ultraviolet light (UVB, 315-280 nm; $12 / 12$ hour photoperiod) at $25^{\circ} \mathrm{C}$. Cardinal temperatures for growth: between 5 and $30^{\circ} \mathrm{C}$, with an optimum of $25^{\circ} \mathrm{C}$, at which colonies averaged $27 \mathrm{~mm}$ on PDA after 5 days. Asexual morph unknown.

Hosts - Plurivorous.

Known distribution - AUSTRALIA; BRAZIL; CENTRAL AFRICAN REPUBLIC; CHINA; COLOMBIA; EQUADOR; FRANCE; INDIA; ITALY; JAPAN; NAMIBIA; PAPUA NEW GUINEA; PARAGUAY; PHILIPPINES; PORTUGAL; REPUBLIC OF THE UNION OF MYANMAR; SIERRA LEONE; UNITED STATES.

Material examined - AUSTRALIA, Western Australia, Upper Swan, Noack Road, 300m east of the Great Northern Highway, 31 ${ }^{\circ} 46$ '55.30" S, 116.01'40.74” E, 10m asl., discarded canes of $V$. vinifera cv. Cabernet Sauvignon, November 2009, leg. F.P. Trouillas (ascomata on host material, DAR80529); New South Wales, Cessnock, Wine Country Drive, 3.1km north of Cessnock, $32^{\circ} 48^{\prime} 25.66^{\prime \prime} \mathrm{S}, 151^{\circ} 20^{\prime} 57.83^{\prime \prime} \mathrm{E}, 66 \mathrm{~m}$ asl., fallen branches of $F$. angustifolia subsp. angustifolia, September 2013, leg. W.M. Pitt (living culture and ascomata on host material, DAR82454); Pokolbin, Pokolbin Mountain Road, 650m west of McDonalds Road, 32 48'23.30" S, 151'16'29.20" E, $133 \mathrm{~m}$ asl., discarded canes of V. vinifera cv. Shiraz, September 2013, leg. W.M. Pitt (living culture, DAR82455).

\section{Discussion}

Previously, we described a bitunicate ascomycete from grapevines that had brown 1-septate ascospores consistent with Dothiorella and Spencermartinsia, two botryosphaeriaceous genera known to be associated with Botryosphaeria dieback of grapevines (Pitt et al. 2013). At the time, the fungus was purported to be connected with an asexual morph in Spencermartinsia and we implied, albeit tentatively, that we had observed a new asexual morph-sexual morph relationship in this genus. However, additional morphological studies and DNA sequence comparisons described here have now identified the ascomycete as Munkovalsaria donacina and revealed that the fungus is neither connected to an asexual morph in Spencermartinsia, nor related to the Botryosphaeriaceae (Botryosphaeriales), and in fact resides in a different family and order (Dacampiaceae, Pleosporales).

Munkovalsaria was originally introduced by Aptroot (1995) to accommodate the redisposition of two species from Didymosphaeria Fuck., including Didymosphaeria donacina (Niessl.) Sacc. recombined as $M$. donacina, the generic type, and a second unnamed species from Frisullo et al. (1989) that the author described as Munkovalsaria rubra Aptroot, Van der Aa \& O. Petrini. The genus Munkovalsaria is characterized by clavate bitunicate asci comprising eight brown, thick- 
walled, 1-septate ascospores not unlike the sexual morphs of Spencermartinsia, and currently comprises three species following the addition of Munkovalsaria appendiculata Aptroot (Aptroot 2004). Yet, while the sexual morphs of these species, especially those of M. donacina, are found readily on the stems and branches of numerous woody hosts (Aptroot 1995), their asexual morphs remain elusive, and rather than coelomycetous, are considered hyphomycetous in character (Aptroot 1995, 2004, Gams 2000), and hence, could not be connected with a sexual morph in Spencermartinsia.

While every effort was made to confirm what we believed to be a genuine asexual morphsexual morph connection in Spencermartinsia, including the use of an industry standard technique for the establishment of single ascospore cultures (Crous 2000), it is not uncommon for several different species to be present on a single host, nor given the method, for the propagules of such, to lay together in one spot, making them difficult to separate. Thus, in retrospect there seems little doubt that pycnidia of a Spencermartinsia sp. were also present on host material collected during the initial study, and no doubt that conidia of such were discharged along with ascospores of $M$. donacina onto awaiting plates. Thereafter, germinating conidia were obviously confused with ascospores of similar size, shape, colour and degree of septation. However, our previous report (Pitt et al. 2013) was not the first to connect Munkovalsaria to a coelomycete, nor to an asexual morph in the Botryosphaeriaceae, with Anahosur (1971) linking M. donacina, then D. donacina, to Diplodia.

In that study, from single ascospore cultures obtained from Wild Sage (Lantana camara L.), the author reported a pycnidial fungus resembling Diplodia with dark-brown, two-celled conidia of dimensions $16-20 \times 2-4 \mu \mathrm{m}$. While this description and the photographs provided by the author more closely resemble what we now know as Dothiorella, the widths of conidia did not conform to any Diplodia, nor Dothiorella species currently known from culture (Phillips et al. 2013), and the only specimen of Didymosphaeria traceable to the author during this period arose from Indigoberry (Randia dumetorum Lam.), since re-described as Mycomicrothelia subfallens (Müll. Arg.) D. Hawksw. (Aptroot 1995). Furthermore, the only specimens from Sage were Calospora lantanae Anahosur and Tryblidaria maharastrensis Anahosur (Anahosur 1969). Still, if Anahosur (1971) did isolate asexual morphs of Diplodia or Dothiorella in association with Munkovalsaria, not unlike we did from grapevines (Pitt et al. 2013), then perhaps these genera merely occupy similar hosts and environments. Conversely, Anahosur (1971) may have isolated instead, one of a number of other quite similar species, or actually meant 'Diplodia-like', when he referred to the appearance of the conidia.

Munkovalsaria donacina is plurivorous and pantropical to nearly cosmopolitan in distribution, and prior to this study had been isolated from as many as 36 species within 22 families (Aptroot 1995, Hyde et al. 1999, Wang et al. 2004, Thuang 2008). Early reports also linked the fungus to leaf spot of Cluster Yam (Dioscorea dumetorum (Kunth) Pax) in Nigeria (Emua \& Fajola 1981) and to stem death of Sage in India (Anahosur 1971), but specimens from Yam were re-examined and transferred to Phaeodothis winteri (Niessl) Aptroot (Aptroot 1995), and those from Sage could not be verified. In contrast, $M$. donacina has only been reported on one prior occasion in Australia, with Hyde et al. (1999) isolating the fungus from climbing palm (Calamus australis Mart.) in Queensland. To our knowledge, this is the first report of $M$. donacina from grapevines and Desert Ash, extending the range of the fungus to 38 species within 24 families.

\section{Acknowledgements}

This work was conducted at Agriculture and Agri-Food Canada, Pacific Agri-Food Research Centre, Summerland, British Columbia, Canada. We thank Paula Haag for technical assistance.

\section{References}

Abdollahzadeh J, Javadi A, Zare R, Phillips AJL. 2014 - A phylogenetic study of Dothiorella and Spencermartinsia species associated with woody plants in Iran, New Zealand, Portugal and Spain. Persoonia 32, 1-12. 
Anahosur KH. 1969 - Some note-worthy ascomycetes from Maharashtra, India. Sydowia 23, 63-68.

Anahosur KH. 1971 - The conidial state of Didymosphaeria donacina. Indian Phytopathology 24, $105-108$.

Aptroot A. 1995 - Redisposition of some species excluded from Didymosphaeria (Ascomycotina). Nova Hedwigia 60, 325-379.

Aptroot A. 2004 - Two new ascomycetes with long gelatinous appendages collected from monocots in the tropics. Studies in Mycology 50, 307-311.

Crous PW. 2000 - An improved technique for obtaining single ascospore cultures of ascomycetes. Mycologist 14, 101-103.

Emua SA, Fajola AO. 1981 - Didymosphaeria leaf spot of Cluster Yam (Dioscorea dumetorum). Plant Disease 65, 443-444.

Frisullo S, Sparapano L, Surico G. 1989 - Produzione di fenoli in colture di isolati cromogeni di Didymosphaeria sp. Micologia Italiana 19, 51-56.

Gams W. 2000 - Phialophora and some similar morphologically little-differentiated anamorphs of divergent ascomycetes. Studies in Mycology 45, 187-199.

Hyde KD, Aptroot A, Fröhlich J, Taylor JE. 1999 - Fungi from palms. XLII. Didymosphaeria and similar ascomycetes from palms. Nova Hedwigia 69, 449-471.

Phillips AJL, Alves A, Abdollahzadeh J, Slippers B, Wingfield MJ, Groenewald JZ, Crous PW. 2013 - The Botryosphaeriaceae: genera and species known from culture. Studies in Mycology 76, 51-167.

Phillips AJL, Alves A, Pennycook SR, Johnston PR, Ramaley A, Akulov A, Crous PW. 2008 Resolving the phylogenetic and taxonomic status of dark-spored teleomorph genera in the Botryosphaeriaceae. Persoonia 21, 29-55.

Pitt WM, Úrbez-Torres JR, Trouillas FP. 2013 - Dothiorella vidmadera, a novel species from grapevines in Australia and notes on Spencermartinsia. Fungal Diversity 61, 209-219.

Rayner RW. 1970 - A mycological colour chart. Commonwealth Mycological Institute \& British Mycological Society, Kew.

Rehner SA, Samuels GJ. 1994 - Taxonomy and phylogeny of Gliocladium analyzed by large subunit rDNA sequences. Mycological Research 98, 625-634.

Sánchez ME, Venegas J, Romero MA, Phillips AJL, Trapero A. 2003 - Botryosphaeria and related taxa causing oak canker in southwestern Spain. Plant Disease 87, 1515-1521.

Thuang MM. 2008 - Pathologic and taxonomic analysis of leaf spot and tar spot diseases in a tropical dry to wet monsoon ecosystem of lowland Burma. Australasian Plant Pathology 37, 180-197.

Vilgalys R, Hester M. 1990 - Rapid genetic identification and mapping of enzymatically amplified ribosomal DNA from several Cryptococcus species. Journal of Bacteriology 172, 42384246.

Wang YZ, Aptroot A, Hyde KD. 2004 - Revision of the ascomycete genus Amphisphaeria. Fungal Diversity Press, Thailand.

White TJ, Bruns T, Lee S, Taylor J. 1990 - Amplification and direct sequencing of fungal ribosomal RNA genes for phylogenetics. In: Innis MA, Gelfand DH, Sninsky JJ, White TJ (eds) PCR protocols: a guide to methods and applications. Academic Press, San Diego.

Zhang Y, Schoch CL, Fournier J, Crous PW, de Gruyter J, Woudenberg JHC, Hirayama K, Tanaka K, Pointing SB, Spatafora JW, Hyde KD. 2009 - Multi-locus phylogeny of Pleosporales: a taxonomic, ecological and evolutionary re-evaluation. Studies in Mycology 64, 85-102. 